\title{
PENGARUH DISIPLIN KERJA TERHADAP KINERJA PEGAWAI NEGERI SIPIL (PNS) DI LINGKUNGAN AJUDAN JENDERAL DAERAH MILITER (AJENDAM) - I BUKITBARISAN MEDAN
}

\author{
Oleh : \\ Reza Nurul Ichsan ${ }^{1)}$, Eddi Surianta ${ }^{2)}$, Lukman Nasution ${ }^{3)}$ \\ ${ }^{1}$ Universitas Pembinaan Masyarakat Indonesia, \\ ${ }^{2}$ Universitas Darma Agung Medan, \\ ${ }^{3}$ Universitas Muslim Nusantara Medan, \\ E-mail: \\ rezaichsan31@gmail.com \\ eddisurianta@gmail.com \\ lukmanumnaw@gmail.com
}

\begin{abstract}
Work Discipline is an important thing for the success of every organization, both in government and private organizations / agencies. An organization or government agency will succeed in achieving its goals whenever any individual or employee implements discipline in work. Thus the performance of each member or employee will increase as well as the increased performance of the organization. Likewise with the Office of Ajendam I / BB in Medan. The theory used in this research is the theory relating to human resource management, especially the theory that concerns the discipline of work and performance of employees, both quantitatively and qualitatively. This research was conducted in Ajendam I Bukit Barisan Medan, located at Jalan Gatot Subroto Km 7.6. Field. This research activity is planned to be conducted from May to July 2017. From the discussion that was conducted in accordance with the topic and the subject matter, and the data analysis conducted, it was found that in general by linear regression with $Y$ $=7,541+0,413 X$ by determination which $84,8 \%$, the work discipline had a significant effect on the performance of the employees at Ajendam I Office Bukit Barisan Medan, where t arithmetic was 20.060 while t table 1.984 at $=5 \%$. From the results obtained suggested to the leadership of Ajendam I Bukit Barisan Medan in order to maintain and further improve and foster the discipline of work at the institution, in order to achieve improved overall performance of employees in accordance with expectations.
\end{abstract}

Keywords: employee discipline and civil servant performance 


\begin{abstract}
ABSTRAK
Disiplin Kerja adalah suatu hal yang penting untuk keberhasilan setiap organisasi, baik di pemerintahan maupun organisasi/instansi swasta. Suatu organisasi ataupun instansi pemerintah akan berhasil dalam pencapaian tujuan bilamana setiap individu atau pegawainya menerapkan disiplin dalam bekerja. Dengan demikian kinerja setiap anggota atau pegawai akan meningkat yang sekaligus juga meningkatnya kinerja organisasi tersebut. Demikian juga halnya dengan Kantor Ajendam I/BB di Medan. Teori yang digunakan dalam penelitian ini adalah teori yang berhubungan dengan manajemen sumberdaya manusia terutama teori yang menyangkut tentang disiplin kerja dan kinerja pegawai, baik secara kuantitatif maupun secara kualitatif. Penelitian ini dilakukan di Ajendam I Bukit Barisan Medan yang berlokasi di Jalan Gatot Subroto Km 7.6. Medan. Kegiatan penelitian ini direncanakan akan dilakukan terhitung sejak bulan Mei hingga Juli 2017. Dari pembahasan yang dilakukan sesuai dengan topik dan pokok permasalahan, serta analisis data yang dilakukan diperoleh hasil dalam bentuk regresi linier sederhana yaitu $\mathrm{Y}=7,541+0,413 \mathrm{X}$ dengan determinansi sebesar $84,8 \%$, dan secara umum disiplin kerja berpengaruh signifikan terhadap kinerja pegawai pada Kantor Ajendam I Bukit Barisan Medan, dimana t hitung sebesar 20,060 sedangkan t table 1,984 pada $\alpha=5 \%$. Dari hasil yang diperoleh disarankan kepada pimpinan Ajendam I Bukit Barisan Medan agar menjaga dan lebih meningkatkan serta membina disiplin kerja pada lembaga tersebut, demi tercapainya peningkatan kinerja pegawai secara keseluruhan sesuai dengan harapan.
\end{abstract}

Kata Kunci: disiplin pegawai dan kinerja PNS

\section{PENDAHULUAN}

Pegawai Negeri Sipil juga masih terlihat jauh dari sikap "abdi" dalam memberikan pelayanan yang menjadi tugas mereka. Dharma (2011 : 98) mengatakan kemampuan pelayanan yang dilakukan PNS hanya mencapai 43,98 persen. Fenomena yang hampir sama juga terjadi di jajaran Pegawai Negeri Sipil di lingkungan Ajendam (Ajundan Jenderal Daerah Melitter) Kodam I Bukit Barisan Medan. Pelayanan yang selama ini dilaksanakan, terutama dalam pelayanan administrasi kepegawaian dan keprajuritan, belum memenuhi target yang telah ditetapkan sebelumnya, yaitu penyelesaian administrasi penetapan pensiun
Prajurit TNI pada tahun 2016 hanya tercapai $95.57 \%$ dan administrasi penetapan pensiun pegawai negeri sipil $87.80 \%$.

\begin{tabular}{ccr}
\multicolumn{2}{c}{ Berkaitan dengan kinerja } \\
pelayanan kepegawaian dan
\end{tabular} keprajuritan, PNS Ajendam dituntut untuk menonjolkan citra yang baik dimata, terutama keberadaan atau kondite yang melekat pada setiap PNSnya. Sebagai pegawai yang menangani administrasi kepegawaian dan keprajuritan yang menyangkut nasib dan masa depan PNS dan Prajurit lainnya, PNS Ajendam harus mampu menjalankan peran dan fungsinya secara profesional. Profesionalitas pegawai dalam menjalankan peran dan fungsinya 
menuntut adanya disiplin dalam segala hal sebagai prasyarat tercapainya tujuan organisasi. Pelaksanaan pelatihan pada karyawan akan meningkatkan disiplin dalam bekerja serta sangat berpengaruh terhadap insentif yang diterima ( Sibagariang O, Manalu T \& Girsang W (2019).

\section{TINJAUAN PUSTAKA \\ Disiplin Kerja \\ Pengertian Disiplin Kerja}

Disiplin merupakan tonggak penopang bagi keberhasilan tujuan organisasi, baik organisasi sektor publik (Pemerintahan) maupun sektor swasta. Untuk itu, setiap organisasi harus menerapkan kebijakan disiplin pada pegawai dalam organisasiorganisasi tersebut. Bagi pegawai, disiplin merupakan salah satu kunci keberhasilan dalam menyelesaikan tugas dan kewajibannya. Disisi lain, organisasi juga akan memperoleh manfaat dari penerapan kebijakan disiplin. Tanpa adanya disiplin dan ancaman tindakan disiplin, efektifitas organisasi akan menjadi sangat terbatas.

Saydam

menggambarkan

prosedur yang menghukum melanggar peraturan atau prosedur". Lebih jauh lagi, Simamora (2009: 746) menjelaskan "disiplin sebagai bentuk pengendalian diri pegawai dan pelaksanaan sebuah organisasi".

Siagian

(2016:278), berpendapat Disiplin kerja merupakan suatu sikap menghormati, menghargai, patuh dan taat terhadap peraturanperaturan yang berlaku, baik yang tertulis maupun yang tidak tertulis serta sanggup menjalankan dan tidak mengelak untuk menerima sanksisanksinya apabila ia melanggar tugas dan wewenang yang diberikan kepadanya. Disiplin adalah pelatihan, khususnya pelatihan pikiran dan sikap untuk menghasilkan pengendalian diri, kebiasaan-kebiasaan untuk mentaati peraturan yang berlaku.

Singodimenjo dalam Sutrisno (2011:86), bahwa : "Disiplin adalah sikap kesediaan dan kerelaan seseorang untuk mematuhi dan mentaati norma-norma peraturan yang berlaku di sekitarnya". Hasibuan (2014:190) mendefinisikan disiplin kerja adalah: "Kesadaran dan kesediaan seseorang menaati semua peraturan perusahaan dan normanorma sosial yang berlaku".

\section{Macam-macam Disiplin Kerja.}

Menurut Rivai (2012, 208-211) ada tiga macam kedisiplinan, yaitu: disiplin preventif, disiplin korektif dan disiplin progresif.

1. Disiplin preventif.

2. Disiplin korektif.

3. Disiplin progresif.

\section{Fungsi Disiplin Kerja.}

Fungsi khusus disiplin kerja dapat dijabarkan sebagai peranan penting dalam hidup. Karena memunculkan dampak positif luar biasa yang dapat dirasakan dalam lingkungan kerja. Terutama bagi seseorang pimpinan yang hendak memberikan contoh bagi karyawannya. Pertama, disiplin dapat meningkatkan kualitas karakter. Kualitas karakter akan terlihat pada komitmen seseorang kepada Tuhan, organisasi, diri, orang lain dan kerja.

Puncak komitmen akan terlihat pada integritas diri yang tinggi dan tangguh. Sikap demikian dapat 
mendukung proses peningkatan kualitas karakter, sikap, dan kerja. Di sinilah kualitas sikap (komitmen dan integritas) ditunjang, didukung, dikembangkan dan diwujudkan dalam kenyataan. Komitmen dan integritasakan terlihat dalam kinerja yang konsisten.

Dalam prosesnya, disiplin dapat dilukiskan dengan tiga perbandingan:

1. Disiplin bagai mercusuar yang membuat nahkoda tetapsiaga akan kondusi yang dihadapi dan tetap waspada menghadapi kenyataan hidup dan kerja.

2. Disiplin dapat digambarkan seperti air sungai yang terus mengalir dari gunung ke lembah dan terus membawa kesegaran dan membersihkan bagian sungai yang keruh.

3. Disiplin bagaikan dinamo yang menyimpan kekuatan/daya untuk menghidupkan mesin. Apabila kunci kontak dibuka, dayapun mengalir dan menghidupkan mesin yang menciptakan daya dorong yang lebih besar lagi dan yang berjalan secara konsisten.

\section{Pendekatan Disiplin Kerja}

$$
\text { Menurut Rivai (2012:127), }
$$

Terdapat tiga konsep dalam pelaksanaan disiplin diantaranya adalah aturan tungku panas, tindakan disiplin progresif, dan tindakan disiplin positif. Pendekatan tungku panas dan tindakan progresif terfokus pada perilaku masa lalu, sedangkan pendekatan disiplin positif berorientasi ke masa yang akan datang dalam bekerja sama dengan karyawan untuk memecahkan masalah sehingga masalah itu tidak timbul lagi.

1. Aturan tungku panas.
Pendekatan untuk melaksanakan tindakan disipliner haruslah memiliki konsekuensi yang analog dengan menyentuh sebuah tungku panas :

a. Membakar dengan segera

b. Harus dilaksanakan segera.

c. Memberi peringatan.

d. Memberikan hukuman yang konsisten.

e. Membakar tanpa membedabedakan.

2. Tindakan disiplin progresif.

Tindakan disiplin progresif dimaksudkan untuk memastikan bahwa terdapat hukuman minimal yang tepat terhadap setiap pelanggaran. Pedoman yang dianjurkan yaitu peringatan lisan, peringatan tertulis, kemudian terminasi.

a. Kelalaian dalam pelaksanaan tugas-tugas.

b. Ketidakhadiran kerja tanpa izin.

c. Inefisiensi dalam pelaksanaan pekerjaan.

Pelanggaran yang membutuhkan suatu peringatan tertulis dan selanjutnya terminasi:

a. Tidak berada ditempat kerja.

b. Kegagalan melapor kerja satu atau dua hari berturut-turut.

c. Kecerobohan dalam pemakaian properti perusahaan.

Pelanggaran yang langsung membutuhkan pemecatan diantaranya :

a. Pencurian ditempat kerja.

b. Perkelahian ditempat kerja.

c. Pemalsuan kartu jam hadir kerja.

d. Kegagalan melapor kerja tiga hari berturut-turut tanpa pemberitahuan.

3. Tindakan disiplin positif. 
Tindakan disipliner positif dimaksudkan untuk menutupi kelemahan yang sudah dijelaskan sebelumnya, yaitu mendorong para karyawan memantau perilaku mereka sendiri dan memikul tanggung jawab atas konsekuensi dari tindakan mereka. Persyaratan yang perlu bagi disiplin positif adalah komunikasi, persyaratan pekerjaan dan peraturan kepada para karyawan.

\section{Indikator-Indikator Disiplin Kerja}

Untuk mengetehui lebih jelas tentang disiplin kerja, lebih lanjut menurut Hasibuan (2014: 123) perlu dipahami indikator-indikator yang memengaruhi tingkat kedisplinan karyawan pada suatu perusahaan.

1. Tujuan dan Kemampuan.

1. Teladan Pimpinan.

3. Balas Jasa.

4. Keadilan

5. Waskat.

6. Sanksi Hukuman.

7. Ketegasan.

8. Hubungan Kemanusiaan.

Rivai (2012 : 129) menjelaskan bahwa disiplin kerja memiliki beberapa dimensi, diantaranya adalah sebagai berikut :

1. Kehadiran

2. Ketaatan pada peraturan kerja

3. Ketaatan pada standar kerja

4. Bekerja etis

\section{Sedangkan}

menurut

Soekidjo,2009 : 97), disiplin kerja dipengaruhi oleh faktor yang sekaligus sebagai indikator dari disiplin kerja yaitu :

1. Ketepatan waktu,

2. Menggunakan peralatan kantor dengan baik.

3. Tanggungjawab yang tinggi.

4. Ketaatan terhadap aturan kantor.

Negeri $\begin{array}{ccr}\text { Peraturan } & \text { disiplin } & \text { Pegawai } \\ \text { ditetapkan } & \text { dalam }\end{array}$

Peraturan Pemerintah Nomor 30

Tahun 1980, memuat pokok-pokok:

1. Kewajiban bagi Pegawai Negeri Sipil

a. Setia dan taat sepenuhnya kepada Pancasila, Undangundang Dasar 1945, negara, dan pemerintah:

b. Mengutamakan kepentingan negara di atas kepentingan golongan atau diri sendiri, serta menghindarkan segala sesuatu yang dapat mendesak kepentingan negara oleh kepentingan golongan, diri sendiri, atau pihak lain:

c. Menjunjung tinggi kehormatan dan martabat negara, pemerintah dan Pegawai Negeri Sipil:

d. Mengangkat dan mentaati sumpah/janji Pegawai Negeri Sipil, sumpah/janji jabatan berdasarkan peraturan perundangundangan yang berlaku:

e. Menyimpan rahasia negara dan atau rahasia jabatan dengan sebaik-baiknya:

f. Memperhatikan dan melaksanakan segala ketentuan pemerintah baik yang langsung menyangkut tugas kedinasannya maupun 
yang berlaku secara umum:

g. Melaksanakan tugas kedinasan dengan sebaikbaiknya dan penuh pengabdian, kesadaran, dan tanggung jawab:

h. Bekerja dengan jujur, tertib, cermat, dan bersemangat untuk kepentingan negara:

i. Memelihara dan meningkatkan keuntungan, kekompakkan, persatuan, dan kesatuan korp Pegawai Negeri Sipil:

j. Segera melapor kepada atasannya, apabila mengetahui ada hal yang dapat membahayakan dan merugikan negara/pemerintah, terutama di bidang keamanan, keuangan, dan materiil:

k. Mentaati ketentuan jam kerja:

1. Menciptakan dan memelihara suasana kerja yang baik:

m. Menggunakan dan memelihara barang-barang milik negara dengan sebaik-baiknya:

n. Memberikan pelayanan dengan sebaik-baiknya kepada masyarakat menurut bidang tugasnya masing-masing:

o. Bertindak dan bersikap tegas, tetap adil dan bijaksana terhadap bawahannya:

p. Membimbing bawahannya dalam melaksanakan tugas: q. Menjadi dan memberikan contoh serta teladan yang baik terhadap bawahannya:

r. Mendorong bawahannya untuk meningkatkan prestasi kerjanya:

s. Memberikan kesempatan kepada bawahannya untuk mengembangkan kariernya:

t. Mentaati ketentuan peraturan perundangundangan tentang perpajakan:

u. Berpakaian rapi dan sopan serta bersikap dan bertingkah laku sopan santun terhadap masyarakat, sesama PNS, dan terhadap atasan:

v. Hormat menghormati antara sesama warganegara yang memeluk

Agama/Kepercayaan terhadap Tuhan Yang Maha Esa, yang berlainan:

w. Menjadi teladan sebagai warganegara yang baik dalam masyarakat:

x. Mentaati perintah kedinasan dari atasan yang berwenang:

y. Memperhatikan dan menyelesaikan dengan sebaik-baiknya setiap laporan yang diterima mengenai pelanggaran disiplin.

2. Larangan bagi Pegawai Negeri Sipil

a. Melakukan hal-hal yang dapat menurunkan kehormatan atau martabat 
negara, pemerintah, atau Pegawai Negeri Sipil:

b. Menyalahgunakan wewenang:

c. Tanpa ijin Pemerintah menjadi pegawai atau bekerja untuk negara asing:

d. Menyalahgunakan barangbarang, uang atau suratsurat berharga milik negara:

e. Memiliki, menjual, membeli, menggadaikan, menyewakan, atau meminjamkan barangbarang, dokumen, atau surat-surat berharga milik negara secara tidak sah:

f. Melakukan kegiatan bersama dengan atasan, teman sejawat, bawahan, atau orang lain di dalam maupun di luar lingkungan kerjanya dengan tujuan untuk keuntungan pribadi, golongan, atau pihak lain, yang secara langsung atu tidak langsung merugikan negara:

g. Melakukan tindakan yang bersifat negatif dengan maksud membalas dendam terhadap bawahan atau orang lain di dalam maupun di luar lingkungan kerjanya:

h. Menerima hadiah atau sesuatu pemberian berupa apa saja dari siapapun juga yang diketahui atau patut dapat diduga bahwa pemberian itu bersangkutan dengan jabatan atau pekerjaan
Pegawai Negeri Sipil yang bersangkutan:

i. Memasuki tempat-tempat yang dapat mencemarkan kehormatan atau martabat Pegawai Negeri Sipil, kecuali untuk kepentingan jabatan:

j. Bertindak sewenangwenang terhadap bawahannya:

k. Melakukan sesuatu tindakan atau sengaja tidak melakukan suatu tindakan yang dapat berakibat menghalangi atau mempersulit salah satu pihak yang dilayani sehingga mengakibatkan kerugaian bagi pihak lain yang dilayani:

1. Menghalangi berjalannya tugas kedinasan:

m. Membocorkan dan memanfaatkan rahasia negara yang diketahui karena kedudukan jabatan untuk kepentingan pribadi, golongan atau pihak lain:

n. Bertindak selaku perantara bagi sesuatu pengusaha atau golongan untuk mendapatkan pekerjaan atau pesanan dari kantor/instansi

Pemerintah:

o. Memiliki saham/modal dalam perusahaan yang kegiatan usahanya berada dalam ruang lingkup kekuasaannya:

p. Memiliki saham suatu perusahaan yang kegiatan usahanya tidak berada dalam ruang lingkup kekuasaannya: 
q. Memiliki saham suatu perusahaan yang kegiatan usahanya tidak berada dalam lingkup kekuasaannya yang jumlah dan sifatnya pemilikan itu sedemikian rupa sehingga melalui pemilik saham tersebut dapat langsung atau tidak langsung menentukan

penyelenggaraan atau jalannya perusahaan:

r. Melakukan kegiatan usaha dagang baik secara resmi, maupun sambilan, menjadi direksi, pimpinan atau komisaris perusahaan swasta bagi yang berpangkat Pembina Golongan Ruang IV/a ke atas atau memangku jabatan Eselon I:

s. Melakukan pungutan tidak sah dalam bentuk apapun juga dalam melaksanakan tugasnya untuk kepentingan pribadi, golongan, atau pihak lain.

3. Sanksi apabila kewajiban tidak ditaati atau larangan dilanggar. Sesuai Pasal 5 Peraturan Pemerintah Nomor 30 Tahun 1980, seorang Pegawai Negeri Sipil yang melanggar disiplin peraturan Disiplin Pegawai Negeri Sipil dapat dijatuhi hukuman berupa:

a. Hukuman Pidana

b. Hukuman Disiplin

Penjatuhan hukuman disiplin dibagi atas beberapa tingkatan dan jenisnya, yaitu:

a. Jenis hukuman disiplin ringan, terdiri dari:

1) Teguran lisan:
2) Teguran tertulis:

3) Pernyataan tidak puas secara tertulis.

b. Jenis hukuman disiplin sedang, terdiri dari:

1) Hukuman disiplin berupa penundaan kenaikan gaji:

2) Hukuman disiplin berupa penurunan gaji berkala:

3) Penundaan Kenaikan Pangkat.

c. Jenis hukuman disiplin berat, terdiri dari:

1) Penurunan pangkat:

2) Pembebasan dari Jabatan:

3) Pemberhentian dengan hormat:

4) Pemberhentian tidak dengan hormat

Saydam (2007: 204) menyebutkan beberapa ukuran untuk mengukur disiplin, yakni adanya kepatuhan pegawai pada:

1. Mentaati jam kerja masuk dan jam kerja pulang:

2. Mematuhi pemakaian pakaian seragam lengkap dengan atribut dan tanda pengenalnya:

3. Ikut serta dalam setiap upacara yang diwajibkan:

4. Bersikap dan bertingkah laku sopan santun terhadap semua karyawan, atasan dan anggota masyarakat lainnya.

\section{Kinerja Pegawai.}

\section{Pengertian Kinerja Pegawai.}

Kinerja merupakan perilaku organisasi yang secara langsung berhubungan dengan produksi barang atau penyampaian jasa. Menurut Rivai (2012: 191) kinerja adalah kesediaan 
seseorang atau kelompok orang untuk melakukan sesuatu kegiatan dan menyempurnakannya sesuai dengan tanggung jawab dengan hasil seperti yang diharapkan.

Kinerja merupakan hasil kerja atau karya yang dihasilkan oleh masing-masing pegawai untuk membantu badan usaha dalam mencapai dan mewujudkan tujuan badan usaha. Pada dasarnya kinerja dari seseorang merupakan hal yang bersifat individu karena masingmasing dari pegawai mempunyai tingkat kemampuan yang berbeda. Kinerja seseorang tergantung pada kombinasi dari kemampuan, usaha dan kesempatan yang diperoleh. Lingkungan kerja yang menyenangkan akan menjadi kunci pendorong bagi pegawai untuk menghasilkan kinerja puncak (Dale 2008: 208).

Kata kinerja berasal dari akar kata "to perfom" yang rnempunyai beberapa "entries" berikut (Sayadi 2009: 210):

1. Melakukan, menjalankan, melaksanakan.

2. Memenuhi atau menjalankan kewajiban suatu nazar.

3. Menggambarkan suatu karakter dalam suatu permainan.

4. Menggambarkannya dengan suara atau alat musik.

5. Melaksanakan atau menyempurnakan tanggungjawab.

6. Melakukan suatu kegiatan dalam suatu permainan.

7. Memainkan (pertunjukan) musik.

8. Melakukan sesuatu yang diharapkan oleh seseorang atau mesin.
Kelangsungan hidup suatu perusahaan sangat tergantung pada kinerja pegawai/pegawai dalam melaksanakan pekerjaan, karena itu pegawai merupakan unsur perusahaan terpenting yang harus mendapat perhatian. Pencapaian tujuan perusahaan menjadi kurang efektif apabila pegawai banyak yang tidak berprestasi dengan baik oleh sebab itu perusahaan harus dapat memotivasi pegawainya agar dapat berprestasi kerja dengan optimal agar tujuan perusahaan dapat tercapai.

Menurut Mangkunegara (2010:67) dalam bukunya Manajemen Sumber Daya Manusia Perusahaan, mengemukakan pengertian kinerja sebagai berikut : "Kinerja adalah hasil kerja secara kualitas dan kuantitas yang dicapai oleh seorang pegawai dalam melaksanakan tugasnya sesuai dengan tanggung jawab yang diberikanya."

Menurut

Schemerhorn

(Binangun, 2012: 113) menyatakan bahwa kinerja adalah "Job performance is the quantity and quality of task accomplishments by an individual or group at work" (kinerja adalah kuantitas dan kualitas pekerjaan yang dapat diselesaikan oleh individu ataupun kelompok dalam bekerja.)

Menurut Cherrigton (Simamora 2009: 125) menyatakan bahwa prestasi kerja adalah "job performance is the amount of successful roleachievement" (kinerja merupakan banyaknya keberhasilan pencapaian peran.)

Menurut Griffin (2012: 445) menyatakan bahwa prestasi kerja adalah "Achivement is the desire to accomplish a goal or task more effectively than in the past' prestasi kerja adalah keinginan untuk melakukan suatu tujuan/pekerjaan 
secara lebih efektif daripada masa lampau.

Menurut Filippo (2013: 151) mengungkapkan bahwa "prestasi kerja adalah sesuatu yang dikerjakan / produk dan jasa yang dihasilkan atau diberikan seseorang / sekelompok orang.

Menurut Bambang Guritno dan Waridin (2010: 178) kinerja merupakan perbandingan hasil kerja yang dicapai oleh pegawai dengan standar yang telah ditentukan. Sedangkan menurut Hakim (2010: 97) mendefinisikan kinerja sebagai hasil kerja yang dicapai oleh individu yang disesuaikan dengan peran atau tugas individu tersebut dalam suatu perusahaan pada suatu periode waktu tertentu, yang dihubungkan dengan suatu ukuran nilai atau standar tertentu dari perusahaan dimana individu tersebut bekerja. Kinerja merupakan perbandingan hasil kerja yang dicapai oleh pegawai dengan standar yang telah ditentukan.

$$
\text { Tika (2008: }
$$

mengemukakan bahwa ada 4 (empat) unsur-unsur yang terdapat dalam kinerja yaitu hasil-hasil fungsi pekerjaan, faktor-faktor yang berpengaruh terhadap prestasi pegawai, pencapaian tujuan organisasi dan periode waktu tertentu.

Menurut Rivai (2012: 197) kinerja pada dasarnya ditentukan oleh tiga hal, yaitu kemampuan, keinginan dan lingkungan. Kinerja adalah sesuatu yang dikerjakan atau produk atau jasa yang dihasilkan oleh seseorang atau kelompok, bagaimana mutu kerja, ketelitian dan kerapian kerja, penugasan dan bidang kerja, penggunaan dan pemeliharaan peralatan, inisiatif dan kreativitas, disiplin, dan semangat kerja (kejujuran, loyalitas, rasa kesatuan dan tanggung jawab serta hubungan antar pribadi). Dengan demikian dapat dikatakan bahwa kinerja merupakan sejumlah output dari outcomes yang dihasilkan suatu kelompok atau organisasi tertentu baik yang berbentuk materi (kuantitatif) maupun yang berbentuk nonmateri (kualitatif).

Rivai (2012: 198) menyebutkan empat aspek kinerja yaitu kemampuan, penerimaan tujuan perusahaan, tingkat tujuan yang dicapai dan interaksi antara tujuan dan kemampuan para pegawai dalam perusahaan.

Tujuan kinerja menurut Rivai (2012: 198):

1. Kemahiran dari kemampuan tugas baru diperuntukan untuk perbaikan hasil kinerja dan kegiatannya.

2. Kemahiran dari pengetahuan baru dimana akan membantu pegawai dengan pemecahan masalah yang kompleks atas aktivitas membuat keputusan pada tugas.

3. Kemahiran atau perbaikan pada sikap terhadap teman kerjanya dengan satu aktivitas kinerja.

4. Target aktivitas perbaikan kinerja.

5. Perbaikan dalam kualitas atau produksi.

6. Perbaikan dalam waktu atau pengiriman.

Menurut Simamora (2009: 123) mengemukakan bahwa kinerja dapat dilihat dari indiktor-indikator sebagai berikut :

1. Keputusan terhadap segala aturan yang telah ditetapkan organisasi.

2. Dapat melaksanakan pekerjaan atau tugasnya tanpa kesalahan (atau dengan tingkat kesalahan yang paling rendah).

3. Ketepatan dalam menjalankan tugas. 
Ukuran kinerja secara umum yang kemudian diterjemahkan ke dalam penilaian perilaku secara mendasar meliputi:

1. mutu kerja:

2. kuantitas kerja:

3. pengetahuan tentang pekerjaan:

4. pendapat atau pernyataan yang disampaikan:

5. keputusan yang diambil:

6. perencanaan kerja:

7. daerah organisasi kerja.

\section{Faktor - faktor yang Mempengaruhi} Kinerja.

Menurut Bernardin dan Russel (2012: 233) bahwa kinerja dipengaruhi oleh kemampuan dan usaha kerja individu serta kemampuan kerja yang diperoleh individu atau pegawai tersebut dalam pekerjaannya. Kinerja atau performace berhubungan dengan variabel individual dan variabel situasional. Variabel individual merupakan sikap, karakteristik kepribadian, karakteristik fisik, motivasi, usia, jenis kelamin, pendidikan, pengalaman dan personal variabel lainnya. Situasi variabel terdiri dari physical dan job variabel, serta variabel situasional yang meliputi metode kerja, ruang dan susunan kerja, serta lingkungan fisik, karakter organisasi, pelatihan dan supervisi, tipe insentif/kompensasi dan lingkungan sosial.

Kinerja adalah hasil kerja secara kualitas dan kuantitas yang dilakukan oleh individu atau kelompok dalam melaksanakan tugas dan perannya sesuai dengan tanggung jawab yang diberikan kepadanya secara efektif. Kinerja merupakan sesuatu yang dicapai atau prestasi yang diperlihatkan atau kemampuan bekerja, dengan kata lain bahwa kinerja dapat diartikan sebagai prestasi kerja. Menurut Gibson et al (2007: 175), faktor-faktor individual yang mempengaruhi kinerja meliputi kemampuan fisik, kemampuan mental (intelegensi) danketerampilan, faktor demografis (misal umur, jenis kelamin, ras, etnik, dan budaya) serta variabelvariabel psikologis (persepsi, atribusi, sikap, dan kepribadian). Variabel lingkungan pekerjaan (job design, peraturan dan kebijakan, kepemimpinan, sumber daya, penghargaan serta sanksi) dan non pekerjaan (keluarga, keadaan ekonomi serta hobi) juga berpengaruh pada perilaku bekerja yang akhirnya membentuk kinerja seseorang.

Kinerja merupakan kuantitas dan kualitas pekerjaan yang diselesaikan oleh individu, maka kinerja merupakan output pelaksanaan tugas. Kinerja mempunyai hubungan yang erat dengan masalah produktivitas, karena merupakan indicator dalam menentukan bagaimana usaha untuk mencapai tingkat produktivitas yang tinggi dalam suatu organisasi. Hasibuan (2014: 79) menyatakan bahwa: produktivitas adalah perbandingan antara keluaran (output) dengan masukan (input).

Faktor-faktor yang mempengaruhi kinerja menurut Sedarmayanti (2007: 93) antara lain:

1. Sikap mental (motivasi kerja, disiplin kerja, etika kerja):

2. Pendidikan:

3. Keterampilan:

4. Manajemen kepemimpinan:

5. Tingkat penghasilan:

6. Gaji dan kesehatan:

7. Jaminan sosial

8. Iklim kerja: 
9. Sarana prasarana:

10. Teknologi:

11. Kesempatan berprestasi.

Menurut Flippo (2013: 150 ), kinerja merupakan gabungan dari beberapa faktor yang berperan penting yaitu :

1. Kualitas dan kuantitas kerja yang meliputi ketelitian, kelengkapan, ketepatan dan kerapihan.

2. Tanggungjawab yang merupakan beban yang ditanggung dalam pekerjaan.

3. Kemampuan untuk memimpin.

4. Kesanggupan untuk bekerja sama dengan semua pihak.

5. Inisiatif yaitu kontribusi pelaksanaan kerja atas prakarsa sendiri.

6. Kesetiaan/loyalitas dalam melaksanakan pekerjaan.

7. Ketaatan dalam mematuhi peraturan.

8. Kejujuran di dalam mengemban tugas.

Untuk mencapai kinerja yang lebih baik maka perlu diperhatikan bahwa ada beberapa faktor-faktor yang mempengaruhi kinerja yaitu faktor kemampuan dan faktor motivasi agar kinerja pegawai terlaksana dengan baik.

Menurut Davis dalam Mangkunegara (2010: 71) faktor mempengaruhi pencapaian kinerja adalah faktor kemampuan (ability) dan faktor motivasi (motivation) yang merumuskan bahwa Human performance adalah Ability +motivation, Motivation adalah Attitude + Situtation, dan Ability adalah Knowledge + Skill.
1. Human performance $=$ Ability + motivation

Artinya setiap pegawai harus memiliki kemampuan dan motivasi agar dapat tercapai kinerja yang baik dalam menjalankan tugas atau pekerjaanya.

2. Motivation $=$ Attitude + Situtation Motivasi terbentuk dari sikap (attitude ) seorang pegawai dalam menghadapi situasi (situation) kerja. Motivasi merupakan kondisi yang menggerakkan diri pegawai yang terarah untuk mencapai tujuan organisasi (tujuan kerja).

3. Ability $=$ Knowledge + Skill

Secara psikologis, kemampuan (ability) pegawai terdiri dari kemampuan potensi dan kemampuan reality (knowledge + skill). Artinya, pegawai yang memiliki pengetahuan dengan pendidikan yang memadai untuk jabatannya dan terampilan dalam mengerjakan pekerjaan sehari-hari lebih mudah mencapai kinerja yang diharapkan. oleh karena itu, pegawai perlu sitempatkan pada pekerjaan yang sesuai dengan keahliannya.

Dari uraian di atas maka dapat diartikan bahwa setiap pegawai harus mempunyai skill (keahliaan), knowledge (pengetahuan), motivation (motivasi) dan attitude (sikap) agar dapat menjalankan tugas dan fungsinya dengan baik dan bertanggung jawab.

\section{Kerangka Pemikiran}

Dari pemaparan sebelumnya dan variabel yang diajukan dalam penelitian ini maka diajukan kerangka pemikiran sebagai berikut: 
Gambar 3.1. Kerangka Pemikiran

Sumber : diolah penulis 2017

\section{METODOLOGI PENELITIAN Lokasi dan Waktu Penelitian}

Penelitian ini dilakukan pada Ajendam I Bukit Barisan Medan yang berlokasi di Jalan Gatot Subroto Km 7.6. Medan. Kegiatan penelitian ini direncanakan akan dilakukan terhitung sejak bulan Mei hingga Juli 2017.

\section{Populasi dan Sampel Populasi}

Dalam setiap penelitian ilmiah selalu dihadapkan pada masalah populasi dan sampel, karena populasi dan sampel penelitian merupakan sumber data yang akan digunakan untuk mencapai tujuan penelitian. Populasi merupakan totalitas semua nilai yang mungkin hasil menghitung ataupun pengukuran kuantitatif mengenai karakteristik tertentu dari semua anggota kumpulan lengkap dan jelas yang ingin dipelajari sifatnya. Dalam penelitian ini populasi dimaksud adalah PNS di Lingkungan Ajendam I Bukit Barisan pahun 2017 berjumlah 74 orang PNS.

\section{Sampel}

Sampel adalah sekelompok bagian atau porsi tertentu yang diambil dari populasi. Arikunto (2012: 102) menjelaskan bahwa apabila populasi suatu penelitian kurang dari 100 maka sebaiknya dilakukan penelitian populasi, dan sebaliknya apabila populasi suatu penelitian lebih dari 100, maka sebaiknya dilakukan penelitian dengan dengan mengambil beberapa sampel yang dianggap representatif mewakili populasi yang akan di teliti. Jumlah populasi dalam penelitian ini lebih kecil dari 100, yaitu 74 Orang. Dengan demikian penelitian ini disebut penelitian populasi, atau seluruh populasi dijadikan sebagai sampel penelitian dengan teknik sampling jenuh (Sugiyono 2013: 156).

\section{Definisi Operasional dan Pengukuran Variabel Penelitian}

Variabel yang diteliti dalam penelitian ini meliputi satu variabel terikat yang diberi notasi Y, yaitu kinerja PNS dan satu variabel terikat yang diberi notasi $\mathrm{X}$, yaitu Disiplin Kerja. Secara operasional variabel terikat kinerja PNS (Y) didefinisikan sebagai suatu hasil kerja atau outcome yang dicapai oleh seorang pegawai dalam melaksanakan tugasnya sesuai dengan tanggung jawab yang diberikan kepadanya selama periode tertentu. Kinerja PNS dalam penelitian ini dijelaskan dengan menggunakan 7 (tujuh) dimensi yaitu : kualitas, kuanitas, pengetahuan tetntang pekerjaan, kreativitas, kerjasama, inisiatif dan tanggung jawab. Sedangkan variabel bebas disiplin kerja, secara operasional didefinisikan sebagai kesadaran dan kesediaan seseorang menaati semua peraturan perusahaan dan norma-norma sosial yang berlaku. Disiplin kerja dalam penelitian ini dijelaskan dengan menggunakan 7 (tujuh) indikator yaitu kesadaran, ketepatan waktu, menggunakan peralatan kantor dengan baik, tanggungjawab yang tinggi, ketaatan terhadap aturan kantor, ketegasan, sanksi hukuman

Untuk lebih jelasnya, definisi operasional variabel dalam penelitian ini, dimatriks dalam Tabel 3.2. berikut ini.

Tabel 1. Definisi Operasional Variabel 


\begin{tabular}{|c|c|c|c|}
\hline $\begin{array}{l}\text { Va } \\
\text { ria } \\
\text { bel }\end{array}$ & Definisi & Indikator & $\begin{array}{c}\text { Sk } \\
\text { al } \\
\text { a }\end{array}$ \\
\hline $\begin{array}{l}\text { Di } \\
\text { sip } \\
\text { lin } \\
\text { Ke } \\
\text { rja } \\
(\mathrm{X} \\
\text { ) }\end{array}$ & $\begin{array}{l}\text { Suatu } \\
\text { keadaan } \\
\text { yang } \\
\text { menunjukk } \\
\text { an suasana } \\
\text { tertib dan } \\
\text { teratur } \\
\text { yang } \\
\text { dihasilkan } \\
\text { oleh } \\
\text { pegawai } \\
\text { yang } \\
\text { berada } \\
\text { dalam } \\
\text { suatu } \\
\text { organisasi, } \\
\text { dimana } \\
\text { peraturan } \\
\text { yang } \\
\text { berlaku } \\
\text { dalam } \\
\text { organisasi } \\
\text { tersebut } \\
\text { dihormati } \\
\text { dan } \\
\text { dipatuhi. }\end{array}$ & $\begin{array}{l}\text { 1. Kesadaran } \\
\text { 2. Ketepatan } \\
\text { waktu, } \\
\text { 3. Mengguna } \\
\text { kan } \\
\text { peralatan } \\
\text { kantor } \\
\text { dengan } \\
\text { baik } \\
\text { 4. Tanggungj } \\
\text { awab yang } \\
\text { tinggi. } \\
\text { 5. Ketaatan } \\
\text { terhadap } \\
\text { aturan } \\
\text { kantor } \\
\text { 6. Ketegasan. } \\
\text { 7. Sanksi } \\
\text { hukuman. } \\
\text {. }\end{array}$ & $\begin{array}{l}\mathrm{Li} \\
\mathrm{ke} \\
\mathrm{rt}\end{array}$ \\
\hline $\begin{array}{l}\mathrm{Ki} \\
\text { ner } \\
\text { ja } \\
\mathrm{PN} \\
\mathrm{S} \\
(\mathrm{Y} \\
\text { ) }\end{array}$ & $\begin{array}{l}\text { Perbanding } \\
\text { an hasil } \\
\text { kerja yang } \\
\text { dicapai } \\
\text { oleh } \\
\text { pegawai } \\
\text { baik secara } \\
\text { individu } \\
\text { maupun } \\
\text { secara } \\
\text { kelompok } \\
\text { dengan } \\
\text { standar } \\
\text { yang telah } \\
\text { ditentukan, } \\
\text { sehingga } \\
\text { capaian }\end{array}$ & $\begin{array}{l}\text { 1. Kualitas, } \\
\text { 2. kuanitas } \\
\text { 3. Pengetahua } \\
\text { n tentang } \\
\text { pekerjaan } \\
\text { 4. Kreativitas } \\
\text { 5. Kerjasama } \\
\text { 6. Inisiatif } \\
\text { 7. Tanggung } \\
\text { jawab }\end{array}$ & $\begin{array}{l}\mathrm{Li} \\
\mathrm{ke} \\
\mathrm{rt}\end{array}$ \\
\hline
\end{tabular}

\begin{tabular}{|l|l|l|}
\hline hasil & \\
tersebut & & \\
dapat & & \\
diukur & & \\
baik secara & & \\
kuantitatif & & \\
maupun & & \\
secara & & \\
kualitatif. & & \\
\hline
\end{tabular}

Sumber : Diolah penulis 2017

\section{Jenis dan Sumber Data}

Jenis data menurut sumbernya yaitu; data internal dan data eksternal (Soeratno, 2010:69).

1. Data internal adalah data yang dikumpulkan dan hasilnya untuk keperluan lembaga itu pula, misalnya catatan akuntansi, produksi, inventaris, penjualan, personalia dan administrasi perusahaan atau organisasi yang bersangkutan.

2. Data eksternal. Data ini terdiri dari data primer dan data sekunder. Data primer dikumpulkan dan diolah oleh pihak yang menerbitkan atau menggunakannya. Biasanya dikumpulkan melalui sensus atau sampel dari objek dalam hal ini PNS di Ajendam I Bukit Barisan Medan. Sedangkan data sekunder dalam penelitian ini meliputi: dokumen-dokumen resmi di Ajendam I Bukit Barisan Medan, notulen rapat dan sebagainya. Pengumpulan data ini dilakukan dengan menggunakan studi dokumentasi.

\section{Metode Pengumpulan Data.}

Dalam melaksanakan penelitian dan pengumpulan data/informasi yang dibutuhkan dalam 
penyusunan skripsi ini, penulis mengunakan 2 ( dua ) metode, yaitu :

1. Penelitian Kepustakaan (library research ).

Yaitu teknik pengumpulan data yang bersumber dari bahan bacaan berupa literatur - literatur, majalah - majalah, buku - buku, textbook, dan lain sebagainya yang diperoleh dari kepustakaan.

2. Penelitian lapangan ( field

research).

Yaitu teknik pengumpulan data dan informasi yang bersumber dari objeck penelitian dengan jalan mendatangi instansi Kantor Ajendam I Bukit Barisan, memperoleh data-data instansi yang bersangkutan meliputi catatan-catatan instansi, buku-buku pedoman, dan laporan kegiatan.

Adapun pengumpulan data yang diperlukan dalam penelitian ini dilakukan dengan:

1. Kuesioner.

Metode kuesioner adalah metode pengumpulan data dengan memberikann pertanyaan yang harus dijawab. yaitu: prinsip penulisan, pengukuran dan penampilan fisik.

2. Wawancara (interview).

Wawancara (interview) yaitu tanya jawab dengan cara mengadakan komunikasi langsung pada pihak yang terkait untuk memperoleh data dan informasi yang diinginkan.

\section{Metode Analisis Data dan Uji \\ Hopotesis \\ Uji Kualitas Data}

Suatu data yang dihasilkan dari jawaban kuesioner penelitian dikatakan berkualitas apabila jawaban yang diberikan memenuhi karakteristik validitas dan reliabel.

1. Uji Validitas

Uji validitas dimaksudkan untuk menilai sejauhmana suatu alat ukur diyakini dapat dipakai sebagai alat untuk mengukur item - item pertanyaan/pernyataan kuesioner dalam penelitian. Teknik yang digunakan untuk mengikur validitas butir pertanyaan/pernyataan kuesioner adalah Korelasi Product Moment dari Karl Pearson (validitas isi/content validity) dengan cara mengkorelasikan masing-masing item pertanyaan/pernyataan kuesioner dan totalnya, selanjutnya membandingkan $\mathrm{r}$ table dengan $\mathrm{r}$ hitung. Instrument dikatakan valid bilamana $r$ hitung dari setiap butir pertanyaan pada masing-masing variabel > 0,3 (Sugoiyono 2015: 220).

2. Uji Reliabilitas

Hasil dari uji reliabilitas digunakan untuk mengetahui instrumen penelitian yang dipakai dapat digunakan berkali-kali pada waktu yang berbeda. Pengujian dilakukan dengan menggunakan teknik cronbach alpha. Instrumen dikatakatan relaibel bilamana setiap butir pertanyaan dari masing-masing variabel mempunyai nilai $\mathrm{r}$ hitung $>0,6$ (Sugoiyono 2015: 220).

\section{Statistik Deskriptif}

Data statistik yang diperoleh dalam penelitian perlu diringkas dengan baik dan teratur. Hal ini dimaksudkan untuk mendapatkan gambaran yang lebih jelas tentang sekumpulan data yang diperoleh baik mengenai sampel atau populasi. 
Analisis deskriptif dalam penelitian ini dilakukan dengan pendekatan, yaitu analisis distribusi frekuensi dengan mentabulasi setiap data yang diperoleh dari lapangan melalui penyebaran angket.

\section{Statistik Regresi Linier Sederhana}

Model analisis data yang digunakan pada penelitian ini dikembangkan dari persamaan regresi linier sederhana. Sesuai dengan permasalahan, tujuan, kerangka konsep dan hipotesis dalam penelitian ini, diformulasikan model analisis data dalam penelitian ini sebagai berikut :

$$
\mathbf{Y}=\mathbf{a}+\mathbf{b} \mathbf{X}+\varepsilon
$$

Dimana :

$$
\begin{aligned}
\mathrm{Y} & =\text { Kinerja PNS Ajendam I Bukit } \\
& \text { Barisan } \\
\mathrm{a} & =\text { Konstanta } \\
\mathrm{b} & =\text { koefisien regresi: } \\
\mathrm{X} & =\text { Disiplin Kerja } \\
\varepsilon & =\text { variabel lain yang tidak } \\
& \text { dikutkan dalam peneleitian }
\end{aligned}
$$

\section{Uji Asumsi Klasik}

Uji asumsi klasik dalam penelitian meliputi: uji normalitas, dan uji heteroskedastisitas.

1. Uji Normalitas

Uji normalitas bertujuan untuk menguji apakah dalam model regresi, variabel terikat dan veriabel bebas keduanya mempunyai distribusi normal atau tidak. Model regresi yang baik adalah memiliki distribusi data normal atau mendekati normal. Pengujian normalitas dalam penelitian ini menggunakan pendekatan uji histogram, p-plot dan scatter plot pada signifikansi $\alpha$ 5\% (Sunyoto, 2011:134).

2. Uji Heteroskedastis
Penyimpangan uji asumsi klasik ini adalah adanya gejala heteroskedastisitas, artinya varians variabel dalam model tidak sama. Konsekuensi dari adanya gejala heteroskedastis adalah penaksir yang diperoleh tidak efisien, baik dalam sampel besar maupun kecil walaupun penaksir diperoleh menggambarkan populasinya dalam arti tidak bias. Untuk mendeteksi ada tidaknya heteroskedastisitas dalam penelitian ini dilakukan dengan model scatter plot. Suatu data dikatakan terbebas dari penyimpangan heteroskedastistias apabila titik-titiknya mempunyai pola yang teratur, baik meneyempit, melebar maupun bergelombang (Sunyoto, 2011:134).

\section{Pengujian Hipotesis}

Pengujian hipotesis dalam penelitian ini dilakukan dengan menggunakan Uji t. Nilai t-statistik tabel, ditentukan dengan tingkat signifikansi $\alpha \quad 5 \%$ dengan derajat kebebasan $\mathrm{df}=(\mathrm{n}-\mathrm{k}-1)$, dimana $\mathrm{n}$ adalah jumlah observasi dan $\mathrm{k}$ adalah jumlah variabel. Perumusan statistik yang digunakan :

Ho : $\beta=0$, artinya Disiplin kerja tidak berpengaruh terhadap kinerja PNS pada Ajendam I Bukit Barisan Medan.

Ha : $\beta \neq 0, \quad$ artinya Disiplin kerja berpengaruh terhadap kinerja PNS pada Ajendam I Bukit Barisan Medan.

Kriteria pengambilan keputusan :

Bila t hitung lebih kecil dari t tabel dan probabilitasnya lebih kecil dari 
$\alpha 5 \%$, maka Ho yang menyatakan disiplin kerja tidak berpengaruh terhadap kinerja PNS pada Ajendam I Bukit Barisan Medan diterima, sedangkan $\mathrm{Ha}$ yang disiplin kerja berpengaruh terhadap kinerja PNS pada Ajendam I Bukit Barisan Medan ditolak.

Sebaliknya jika Bila t hitung lebih besar dari $t$ tabel dan probabilitasnya lebih kecil dari $\alpha$ $5 \%$, maka Ho yang menyatakan disiplin kerja tidak berpengaruh terhadap kinerja PNS pada Ajendam I Bukit Barisan Medan ditolak, sedangkan $\mathrm{Ha}$ yang disiplin kerja berpengaruh terhadap kinerja PNS pada Ajendam I Bukit Barisan Medan diterima.

\section{HASIL DAN PEMBAHASAN}

\section{Karakteristik Responden}

Karakteristik Responden

Berdasarkan Jenis Kelamin

Dari hasil pengumpulan data yang dilakukan dilapangan terhadap responden diperoleh karakteristik responden berdasarkan jenis kelamin sebagai berikut:

Table 2. Karakteristik Responden Berdasarkan Jenis Kelamin

\begin{tabular}{|c|c|c|}
\hline $\begin{array}{c}\text { Jenis } \\
\text { Kelamin }\end{array}$ & $\begin{array}{c}\text { Jumlah } \\
\text { (orang) }\end{array}$ & Persentase \\
\hline Laki-laki & 38 & 51,35 \\
\hline Perempuan & 36 & 48,65 \\
\hline Total & 74 & 100 \\
\hline
\end{tabular}

Sumber: Diolah Penulis berdasarkan data dari lapangan tahun 2017.

\section{Karakteristik Responden Berdasarkan Umur}

Dari hasil pengumpulan data yang dilakukan dilapangan terhadap responden diperoleh karakteristik responden berdasarkan jenis kelamin sebagai berikut:

Table 3. Karakteristik Responden Berdasarkan Umur

\begin{tabular}{|c|c|c|}
\hline Umur & $\begin{array}{c}\text { Jumlah } \\
\text { (orang) }\end{array}$ & $\begin{array}{c}\text { Persentase } \\
(\%)\end{array}$ \\
\hline $\begin{array}{l}20-30 \\
\text { tahun }\end{array}$ & 4 & 5,41 \\
\hline $\begin{array}{l}31-40 \\
\text { tahun }\end{array}$ & 24 & 32,43 \\
\hline $\begin{array}{l}41-50 \\
\text { tahun }\end{array}$ & 31 & 41,89 \\
\hline $\begin{array}{l}51-60 \\
\text { tahun }\end{array}$ & 15 & 20,27 \\
\hline Jumlah & 74 & 100 \\
\hline
\end{tabular}

Sumber: Diolah Penulis berdasarkan data dari lapangan tahun 2017.

\section{Karakteristik Responden Berdasarkan Jarak Tempat Tinggal}

Dari hasil pengumpulan data yang dilakukan dilapangan terhadap responden diperoleh karakteristik responden berdasarkan jarak tempat tinggal sebagai berikut sebagai berikut:

Table 4. Karakteristik Responden Berdasarkan Jarak Tempat Tinggal

\begin{tabular}{|l|c|c|}
\hline Jarak & $\begin{array}{l}\text { Jumlah } \\
\text { (orang) }\end{array}$ & $\begin{array}{l}\text { Persentase } \\
(\%)\end{array}$ \\
\hline $0-2 \mathrm{~km}$ & 11 & 13,51 \\
\hline$>2-4 \mathrm{~km}$ & 32 & 43,24 \\
\hline$>4-6 \mathrm{~km}$ & 26 & 35,14 \\
\hline$>6-8 \mathrm{~km}$ & 6 & 8,11 \\
\hline Jumlah & 72 & 100 \\
\hline
\end{tabular}

Sumber: Diolah Penulis berdasarkan data dari lapangan tahun 2017.

Karakteristik Responden Berdasarkan Tingkat Pendidikan 
Dari hasil pengumpulan data yang dilakukan dilapangan terhadap responden diperoleh karakteristik responden berdasarkan tingkat pendidikan sebagai berikut sebagai berikut:

Tabel 5. Karakteristik Responden Berdasarkan Tingkat Pendidikan

\begin{tabular}{|l|c|c|}
\hline Pendidikan & $\begin{array}{l}\text { Jumlah } \\
\text { (orang) }\end{array}$ & $\begin{array}{l}\text { Persentase } \\
(\%)\end{array}$ \\
\hline SLTA & 35 & 47,30 \\
\hline D3 & 8 & 10,81 \\
\hline S1 & 24 & 32,43 \\
\hline S2 & 7 & 9,46 \\
\hline S3 & - & - \\
\hline Jumlah & 74 & 100 \\
\hline
\end{tabular}

Sumber: Diolah Penulis berdasarkan data dari lapangan tahun 2017.

\section{Analisis Deskripsi Variabel Pengujian Kualitas Data}

Sebelum dilakukan pengujian hipotesis, maka perlu dilakukan pengujian kualitas data diantaranya uji validitas dan uji reabilitas data. Uji ini perlu dilakukan karena jenis data penulisan adalah data primer. Pengujian ini dilakukan terhadap 30 orang responden yang tidak termasuk responden dalam penelitian ini. Berdasarkan uji validitas yang dilakukan semua item pertanyaan valid dan dapat digunakan untuk mengolah data. Pengujian validitas dan reliabilitas data dilakukan dengan menggunakan SPPS.

\section{Uji Validitas}

Uji validitas adalah ukuran yang menunjukkan sejauh mana instrumen pengukuran mampu apa yang ingin diukur. Suatu instrumen dianggap valid apabila mampu mengukur apa yang diinginkan.
Dengan kata lain mampu memperoleh data yang tepat dari variabel yang teliti.

Tabel 6. Uji Validitas Butir Pertanyaan Variabel Disiplin Kerja (X)

Item-Total Statistics

\begin{tabular}{|l|r|}
\hline & \multicolumn{2}{|c|}{$\begin{array}{c}\text { Cronbach's } \\
\text { Alpha if Item } \\
\text { Deleted }\end{array}$} \\
\hline X1 & $\mathbf{. 7 3 2}$ \\
X2 & $\mathbf{. 7 3 8}$ \\
X3 & $\mathbf{. 7 3 4}$ \\
X4 & $\mathbf{. 7 4 5}$ \\
X5 & $\mathbf{. 7 5 3}$ \\
X6 & $\mathbf{. 7 3 7}$ \\
X7 & $\mathbf{7 4 3}$ \\
XTotal & .801 \\
\hline
\end{tabular}

Sumber : Data uji coba diolah dengan program SPSS tahun 2017

Instrument dikatakan valid bilamana $\mathrm{r}$ hitung $>0,3$ pada Cronbach's Alpha if Item Deleted $\alpha=$ 0,05 (5\%). Dari hasil uji coba diperoleh Cronbach's Alpha masingmasing item variabel Disiplin Kerja (X) sebagaimana digambarkan dalam Tabel 4.5 diatas, semuanya lebih besar dari 0,3. Dengan demikian maka masing-masing butir pertanyaan pada variabel Disiplin Kerja (X) dinyatakan valid.

Tabel 7. Uji Validitas Butir Pertanyaan Variabel Kinerja Pegawai (Y) Item-Total Statistics

\begin{tabular}{|l|r|}
\hline & \multicolumn{1}{|c|}{$\begin{array}{c}\text { Cronbach's } \\
\text { Alpha if Item } \\
\text { Deleted }\end{array}$} \\
\hline Y1 & $\mathbf{. 7 5 3}$ \\
Y2 & $\mathbf{. 7 5 5}$
\end{tabular}




\begin{tabular}{|l|l|} 
Y3 & $\mathbf{. 7 4 9}$ \\
Y4 & $\mathbf{. 7 4 9}$ \\
Y5 & $\mathbf{. 7 5 1}$ \\
Y6 & $\mathbf{. 7 6 3}$ \\
Y7 & $\mathbf{. 7 5 9}$ \\
YTotal & .860 \\
\hline
\end{tabular}

Sumber : Data uji coba diolah dengan program SPSS tahun 2017.

Dari hasil uji coba diperoleh Cronbach's Alpha masing-masing item variabel Kinerja Pegawai (Y) sebagaimana digambarkan dalam Tabel 4.6 diatas, semuanya lebih besar dari 0,3. Dengan demikian maka masing-masing butir pertanyaan pada variabel Kinerja Pegawai dinyatakan valid.

\section{Uji Reliabilitas.}

Variabel penelitian dikatakan valid bila Cronbach's Alpha > 0,6. Dari pengujian terhadap instrument penelitian maka diperoleh bahwa uji reliabilitaas masing-masing instrument variabel menggambarkan bahwa semua instrument variabel penelitian yang digunakan dinyatakan reliable. Hal itu terlihat dari hasil perhitungan yang dilakukan dengan menggunakan program SPSS, dan diperoleh hasil reliabilitas seperti tercantum dalam table masing-masing dibawah ini.

Tabel 8. Uji Reliabilitas Butir Pertanyaan Variabel Disiplin Kerja (X)

\begin{tabular}{|c|c|c|}
\hline & $\begin{array}{c}\text { Cronbach's } \\
\text { Alpha } \\
\text { Based on }\end{array}$ & \\
$\begin{array}{c}\text { Cronbach's } \\
\text { Alpha }\end{array}$ & $\begin{array}{c}\text { Standardize } \\
\text { d Items }\end{array}$ & $\begin{array}{c}\text { N of } \\
\text { Items }\end{array}$ \\
\hline $\mathbf{. 7 6 8}$ & .869 & 8 \\
\hline
\end{tabular}

Sumber : Data uji coba diolah dengan program SPSS tahun 2017
Dari hasil diatas, maka diperoleh bahwa butir pertanyaan dari variabel Disiplin $\operatorname{kerja}(\mathrm{X})$ yang digunakan dalam penelitian ini dinyatakan reliabel. Hal itu terlihat dari Cronbach's Alpha 0,768 yang lebih besar dari 0,6. Karena butir pertanyaan valid dan reliable, maka butir pertanyaan tersebut layak digunakan dalam penelitian.

Tabel 9. Uji Reliabilitas Butir Pertanyaan Variabel Kinerja Pegawai (Y) Reliability Statistics

\begin{tabular}{|c|c|c|}
\hline & $\begin{array}{c}\text { Cronbach's } \\
\text { Alpha } \\
\text { Based on }\end{array}$ & \\
$\begin{array}{c}\text { Cronbach's } \\
\text { Alpha }\end{array}$ & $\begin{array}{c}\text { Standardize } \\
\text { d Items }\end{array}$ & $\begin{array}{c}\text { N of } \\
\text { Items }\end{array}$ \\
\hline .782 & .902 & 8 \\
\hline
\end{tabular}

Sumber : Data uji coba diolah dengan program SPSS tahun 2017.

Dari hasil diatas, maka diperoleh bahwa butir pertanyaan dari variabel Kinerja Pegawai (Y) yang digunakan dalam penelitian ini dinyatakan reliabel. Hal itu terlihat dari Cronbach's Alpha 0,782 yang lebih besar dari 0,6. Karena butir pertanyaan valid dan reliable, maka butir pertanyaan tersebut layak digunakan dalam penelitian.

\section{Pengujian Hipotesis}

Regeresi Linier Sederhana

Regresi Linier sederhana digunakan untuk mengetahui pengaruh Disiplin kerja $(\mathrm{X})$ terhadap Kinerja Pegawai (Y). Seberapa besar pengaruhnya dapat dilihat seperti model berikut :

Model regresi linier berganda: 


$$
\mathbf{Y}=\mathbf{a}+\mathbf{B} \mathbf{X}+\boldsymbol{\varepsilon}
$$

Dimana :

$\mathrm{Y}=$ Kinerja Pegawai

$\mathrm{a}=$ Konstanta (intercept)

$B=$ Koefesien Regresi Variabel X

$\mathrm{X}=$ Disiplin kerja.

$\varepsilon=$ faktor lain yang tidak termasuk dalam penelitian

Tingkat kepercayaan (confidence interval) adalah $95 \%$ atau $\alpha=5 \%$.

Tabel 10. Hasil Pengujian Hipotesis

\begin{tabular}{|c|c|c|c|c|}
\hline \multirow[b]{2}{*}{ Model } & \multicolumn{2}{|c|}{$\begin{array}{l}\text { Unstandar } \\
\text { dized } \\
\text { Coefficient } \\
\text { s }\end{array}$} & \multicolumn{2}{|c|}{$\begin{array}{l}\text { Standa } \\
\text { rdized } \\
\text { Coeffi } \\
\text { cients } \\
\end{array}$} \\
\hline & B & $\begin{array}{l}\text { Std. } \\
\text { Erro } \\
\mathrm{r}\end{array}$ & Beta & $\mathrm{t}$ \\
\hline $1 \quad$ Con & 7.54 & 1.05 & & 7.1 \\
\hline $\begin{array}{l}\text { stant } \\
\text { ) }\end{array}$ & 1 & 6 & & 38 \\
\hline $\begin{array}{l}\text { Disi } \\
\text { plin } \\
\text { Ki }\end{array}$ & .413 & .021 & .921 & $\begin{array}{r}20 . \\
060\end{array}$ \\
\hline
\end{tabular}

a Dependent Variable: Kinerja Sumber: Data primer setelah diolah dengan SPSS tahun 2017.

Berdasarkan hasil regresi dari data primer yang diolah dengan menggunakan SPSS, dengan memperhatikan angka-angka yang terdapat pada Unstandardized Coefficients B, dengan memasukkan angka-angka tersebut persamaan regresi berganda pada persamaan diatas, maka diperoleh persamaan regresi sebagai berikut:

$$
Y=7,541+0,413 X+\varepsilon
$$

Dari persamaan tersebut kita lihat bahwa intersep adalah sebesar 7,541 artinya bidang regresi akan sumbu $\mathrm{Y}$ pada titik 7,541 jika variabel $X$ adalah 0 . Hal itu tidak mungkin terjadi sebab suatu lembaga/instansi pemerintah yang memiliki pegawai tidak memiliki disiplin kerja . Nilai koefisien positif menandakan hubungan yang searah antara variabel bebas dengan variabel terikatnya, bila variabel bebas bertambah maka variabel terikat juga bertambah. Jika nilai koefisien negatif menendakan bahwa hubungan antara variabel bebas dengan variabel terikatnya terbalik, jika variabel bebas bertambah maka variabel terikat akan berkurang.

Dengan asumsi cateris paribus, maka generalisasi hasil penelitian pada persamaan diatas dapat dituliskan dengan mengabaikan variabel lain yang tidak ikut dalam penelitian, sebagai berikut: Sig.

.00

$$
Y=7,541+0,413 X
$$

0 Dari persamaan regresi diatas dapat kita lihat bahwa variabel bebas .09isiplin kerja berbanding lurus dengan Qariabel terikat yaitu kinerja pegawai di Lingkungan Ajudan Jenderal Daerah Militer (Ajendam) - I Bukit Barisan Medan. Dengan kondisi cateris paribus, maka bila terjadi kenaikan variabel X (disiplin kerja) sebesar satu satuan, akan mengakibatkan kenaikan pada variabel Y (kinerja pegawai) sebesar 0,413 satuan. Artinya bahwa apabila terjadi kenaikan pada variabel bebas tersebut akan mengakibatkan kenaikan pada variabel terikatnya. Jika disiplin kerja meningkat, mangakibatkan kinerja pegawai meningkat sesuai dengan hasil penelitian dan pengolahan data yang dilakukan dalam penelitian ini. Dan bilamana disiplin kerja tidak ada atau sama dengan nol, maka kinerja pegawai adalah sebesar 7,541. 


\section{Uji Parsial (Uji t)}

Untuk membuktikan apakah variabel bebas disiplin kerja berpengaruh terhadap variabel terikat kinerja pegawai pada Kantor Ajendam I/BB digunakan kriteria pengujian sebagai berikut:

$\mathrm{H}_{0}: \mathrm{B}_{1}=0$ artinya disiplin kerja tidak berpengaruh terhadap kinerja pegawai pada Kantor Ajendam $\mathrm{I} / \mathrm{BB}$.

$H_{i}: \beta_{1} \neq 0$ artinya disiplin kerja berpengaruh terhadap kinerja pegawai pada Kantor Ajendam I/BB.

Kriteria pengambilan keputusan sebagai berikut:

$\mathrm{H}_{0}$ ditolak jika $\mathrm{t}$ hitung $>\mathrm{t}$ tabel pada $\alpha=5 \%$

$\mathrm{H}_{0} \quad$ diterima jika $\mathrm{t}$ hitung $<\mathrm{t}$ tabel pada $\alpha=5 \%$

Dari table 4.12 diatas, maka diperoleh keterangan bahwa $t_{\text {hitung }}$ pada $\alpha=5 \%$ untuk variabel disiplin kerja adalah 20.060 sedangkan $t_{\text {tabel }}$ pada $\alpha=5 \%$ adalah sebesar 1,984 . Sehingga t hitung $>\mathrm{t}$ tabel pada $\alpha=$ $5 \%$. Dengan demikian variabel disiplin kerja berpengaruh signifikan terhadap kinerja pegawai pada Ajendam I/BB. Maka, $\mathrm{H}_{0}: \beta_{1}=0$ yang menyatakan bahwa disiplin kerja tidak berpengaruh terhadap Kinerja pegawai pada Kantor Ajendam I/BB ditolak, dan $\mathrm{H}_{\mathrm{i}}: \beta_{1} \neq 0$ yang menyatakan bahwa disiplin kerja berpengaruh terhadap kinerja pegawai pada Kantor Ajendam I/BB diterima.

\section{Uji Determinan $\left(\mathbf{R}^{2}\right)$ Hipotesis}

Koefisien determinasi adalah bagian dari keragaman total variabel tak bebas $\mathrm{Y}$ yang dapat diterangkan atau diperhitungkan oleh keragaman variabel bebas $\mathrm{X}$. Uji determinan yang diperoleh dari hasil pengolahan data penelitian adalah sebagaimana tertera pada Table 4.13 berikut:

Tabel 11. Hasil Uji Determinasi Hipotesis

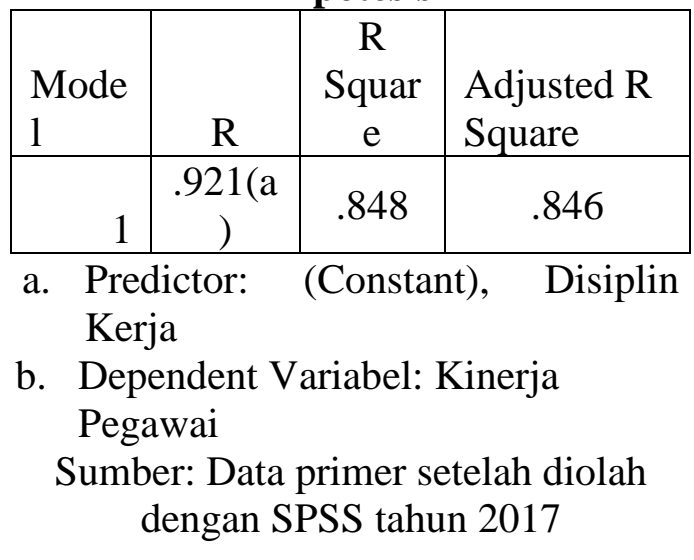

Nilai R Square atau koefisien determinasi pada Tabel 4.13 adalah 0 . 848 artinya sebesar $84,8 \%$ Kinerja Pegawai dalam hal ini dapat dijelaskan oleh variabel disiplin kerja , sedangkan sisanya $15,2 \%$ dijelaskan oleh variabel bebas lainnya yang tidak diikutkan dalam penelitian ini.

\section{PEMBAHASAN}

Dari hasil pengujian hipotesis yang dilakukan, maka diperoleh hasil dimana hipotesis yang diajukan diawal penelitian ini yang menyatakan bahwa "Disiplin kerja berpengaruh terhadap kinerja pegawai pada Kantor Ajendam I/BB" sebagaimana hasil pengujian menunjukkan bahwa hipotesis tersebut dapat diterima. Atau hipotesis yang mengatakan disiplin kerja berpengaruh terhadap kinerja PNS di Lingkungan Ajendam I/BB diterima.

Pengujian digunakan dengan mengumpulkan data primer dilapangan, kemudian diolah sesuai dengan kebutuhan dalam penelitian ini sehingga hasilnya dapat dipertanggungjawabkan secara ilmiah, 
dengan menggunakan level significansy pada $\alpha=5 \%$. Artinya masih ada kemungkinan menerima kesalahan atau membuat kesimpulan yang salah dalam penelitian ini dengan probabilitas 5\%.

Tentu hal ini akan berlaku sebagai generalisasi pada waktu berikutnya bilamana situasi dan kondisi adalah sama dengan kondisi dimana tidak berubah sebagaiaman kondisi yang dialami saat ini. Disisi lain masih banyak faktor yang dapat mempengaruhi, tetapi hal itu tidak termasuk dalam penelitian ini, sebab penelitian ini hanya menguji hipotesis yang sudah diajukan sebelumnya.

Bila dihubungkan dengan penelitian terdahulu yang telah dilakukan oleh peneliti sebelumnya, maka hasil penelitian ini juga sejalan dengan penelitian dari Iman dkk (2014) yang menyatakan disiplin kierja berpengaruh terhadap kinerja pada PT Bank Sulut Cabang Calaca, Laili Siti masrifatul (2014) menyatakan disiplin kierja berpengaruh terhadap kinerja peningkatan kinerja pegawai Pemkab Situbondo, dan penelitian Wariati dkk, (2015) yang menyatakan bahwa disiplin kierja berpengaruh terhadap kinerja Pegawai Dinas Pendapatan Dan Pengelolaan Keuangan Dan Asset Kabupaten Barito Timur.

\section{KESIMPULAN DAN SARAN \\ Kesimpulan}

Dari hasil penelitian dan pengolahan data serta pembahasan yang dilakukan, diperoleh persamaan regresi dengan $\mathrm{Y}=7,541+0,413 \mathrm{X}$, maka dapat disimpulkan bila terjadi kenaikan variabel $\mathrm{X}$ (disiplin kerja) sebesar satu satuan, akan mengakibatkan kenaikan pada variabel Y (kinerja pegawai) sebesar 0,413 satuan dengan determinansi sebesar $84,8 \%$. Hal itu ditunjukkan oleh koefisien disiplin kerja yang mempunyai nilai positif 0,413 . Disamping itu bahwa disiplin kerja berpengaruh signifikan terhadap kinerja pegawai pada Kantor Ajendam I/BB. Hal terlihat dari hasil pengujian dimana nilai $\mathrm{t}$ hitung 20,060 dan $\mathrm{t}$ tabel 1,984 pada df $2=72$ dan $\alpha=$ $5 \%$, dengan demikian $\mathrm{t}$ hitung $>\mathrm{t}$ tabel dan juga sifatnya posititif, dimana semakin tinggi disiplin kerja semakin tinggi pula kinerja pegawainya.

\section{Keterbatasan Penelitian}

Penelitian ini mengalami keterbatasan, dimana tidak semua kepemimpinan, dan kinerja pegawai dapat diungkapkan karena keterbatasan informasi tentang hal tersebut yang dapat diperoleh selama penelitian dilaksanakan, serta adanya keterbatasan saat memperoleh informasi secara rinci dan lengkap. Untuk itu penulis mohon maaf kepada dan memaklumi keterbatasan tersebut, karena tulisan ini bukan bermaksud untuk mendiskreditkan pihak manapun, hanyalah terutama untuk konsumsi ilmiah, dan bukan untuk menilai baik buruknya pihak manapun terlebih instansi yang terkait.

\section{Saran}

$\begin{array}{cr}\text { Sehubungan } & \text { dengan } \\ \text { kesimpulan diatas, maka dapat }\end{array}$ disarankan kepada pimpinan Kantor Ajendam I/BB agar lebih meningkatkan dan membina disiplin kerja pada lembaga tersebut, demi tercapainya peningkatan kinerja pegawai secara keseluruhan sesuai dengan harapan.

\section{DAFTAR PUSTAKA}


Arikunto, Suharsimi. 2012. Prosedur Penelitian Suatu Pendekatan Praktek. Edisi revisi V. Rineka Cipta Jakarta.

Bernardin, H John and Joyce E A Russel, 2012, Human Resource Management, An Experimental Approach, McGraw Hill, Singapore, (Terjemahan). Salemba Empat, Jakarta.

Binangun, Wilson. 2012. Manajemen Sumber Daya Manusia. BPFE, Yogyakarta.

Dale, 2008, Kinerja, PT Elex Media Komputindo, Jakarta.

Davis Keithand John W. Newstrom, 2007 Organizational Behavior, Human Behavior at Work, Auckland.

Flippo, Edwin B. 2013. Manajemen Personalia Edisi Ketujuh, RajaGrafindo, Jakarta.

Gibson, Ivancevich and Donelly, 2007, Organization: Behaviour Structure Processes, Seventh Edition, terjemahan, Salemba Empat. Jakarta.

Griffin. 2012. Manajemen Sumber Daya Manusia. Penerbit Erlangga, Jakarta.

Hakim, Abdul. 2010. Meningkatkan Produktivitas Kerja. PT Rineka Cipta, Jakarta.

Hasibuan, Malayu SP. 2014. Manajemen Sumber Daya Manusia, Edisi Revisi Cetakan
Ketujuh. Bumi Aksara, Jakarta.

Ichsan, RN. L Nasution. Pengaruh Persepsi Kemudahan Penggunaan dan Persepsi Daya Guna Terhadap Minat Nasabah Menggunakan Mandiri Online Pada Bank Mandiri (persero) KCP. Gatot Subroto 2. Prosididing Seminar Nasional Hasil Penelitian. 2 (2), 1128 - 1136.

Ichsan, RN. Kepemimpinan, Komunikasi dan Efektivitas Kerja Pegawai Pemerintah Kota Loksumawe. Jumant, 11 (1), 13-18

Mangkunegara, Anwar Prabu . 2010. Manajemen Sumber Daya Manusia. Remaja Rosdakarya. Bandung.

Mathis, Robert L. dan John H. Jackson, 2012, Manajemen Sumber Daya Manusia (terjemahan), Jakarta: PPM.

Yusuf, M., RN Ichsan. Analisis Efektifitas Penggunaan Cadangan Devisa, Utang Luar Negeri dan Ekspor Terhadap Stabilitas Nilai Tukar. Jurnal Penelitian Pendidikan Sosial Humaniora. 4 (2), 544-561

Mondy, R. W. dan Noe R. M., 2008, Personnel : The Management of Human Resources, Allyn and Bacon Inc., Boston.

Rivai, Veithzal, \& Mulyadi, Deddy. 2012. Kepemimpinan dan 
Perilaku Organisasi,

RajaGrafindo Persada, Jakarta.

Robbins, Stephen. P. 2012. Perilaku organisasi. Edisi Bahasa Indonesia. PT Indeks Kelompok GRAMEDIA. Jakarta

Saydam, Gouzali, 2007, Kamus Istilah Kepegawaian, Jakarta: Pustaka Sinar Harapan.

Sedarmayanti. 2007. Manajemen Sumber Daya Manusia, PT Rineka Cipta. Jakarta.

Siagian, Sondong. P. 2016. Kiat Meningkatkan Produktivitas Kerja, PT Rineka Cipta, Bandung.

Simamora, Henry, 2009, Manajemen Sumber Daya Manusia, Yogyakarta: STIA YKPN.

Sobirin.2014. Manajemen Sumber Daya Manusia. Edisi Ketiga, Penerbit Andi. Yogyakarta.

Soekidjo, $\quad$ Notoatmodjo, 2009. Pengembangan Sumber Daya Manusia, PT Rineka Cipta, Jakarta.

Sugiyono. 2015. Metode Penelitian Manajemen, Alfabeta, Bandung.

Sunyoto, Danang, 2011. Metodologi Penelitian Ekonomi, CAPS, Yogyakarta.

Sutrisno, Edy. 2010. Manajemen Sumber Daya Manusia. Kencana, Jakarta.
Suyadi, $\quad$ Prawirosentono. 2009. Kebijakan Kinerja Karyawan. Yogyakarta.

Tangkilisan, Hesel Nogi S, 2008. Manajemen Publik. Grasindo, Jakarta.

Tika, P. 2008. Budaya Organisasi Dan Peningkatan Kinerja Perusahaan. PT Bumi Aksara. Jakarta.

Waridin. 2010. Manajemen Sumber Daya Manusia, PT Elex Media Komputindo. Jakarta.

Sibagariang, O., Manalu, T., \& Girsang, W. (2019). PENGARUH PELATIHAN DAN DISIPLIN KERJA TERHADAP KINERJA KARYAWAN PADA PT. SANY TOGA GEMILANG. Jurnal Darma Agung, 27(2), 924935. doi:10.46930/ojsuda.v27i2.262 